\title{
A chemometric approach to study the effects of motorway proximity on microelements content in wheat and soil
}

\author{
G. Ludajić • L. Pezo • N. Filipović • \\ J. Filipović
}

Received: 16 February 2013/Revised: 29 April 2014/ Accepted: 21 September 2014/Published online: 8 October 2014 (C) Islamic Azad University (IAU) 2014

\begin{abstract}
The present research was conducted to study contamination and to quantitatively determine the microelements $\mathrm{Pb}, \mathrm{Cd}, \mathrm{Hg}, \mathrm{As}, \mathrm{Zn}, \mathrm{Cu}, \mathrm{Fe}$ and $\mathrm{Mn}$ in roadside soils in the regions in Serbia and in wheat grain grown from those soils. Roadside soil samples and wheat samples were collected from different sites along roadside. Inductively coupled plasma mass spectrometry was used for analysis. Standard scores and the heavy metal index in the soil and wheat grain were calculated by assigning equal weight to applied heavy metals assays. In the soil, the lowest and the highest coefficient of variation were found by determining $\mathrm{Mn}$ and $\mathrm{Hg}$ content as 0.09 and $10.48 \%$, respectively, contrary to the wheat where the lowest and highest coefficient of variation were experienced for $\mathrm{Hg}$ and $\mathrm{Pb}$ at 1.99 and 6.36, respectively. Principal component analysis was applied to the results of analysis comprising the content of eight toxic elements in wheat and soil. It was established that the quantity of analyzed microelements in the wheat is smaller than the quantity found in the soil and the distance from the road contributes to a progressive
\end{abstract}

G. Ludajić $(\square)$

Technical College of Applied Sciences in Zrenjanin, Djordja Stratimirovica 23, 23000 Zrenjanin, Serbia

e-mail: gludajic@gmail.com

L. Pezo

Institute of General and Physical Chemistry, Studentski Trg 12, 11000 Belgrade, Serbia

\section{N. Filipović}

Faculty of Technology, University of Novi Sad, Bulevar cara Lazara 1, 21000 Novi Sad, Serbia

J. Filipović

Institute for Food Technology, University of Novi Sad, Bulevar cara Lazara 1, 21000 Novi Sad, Serbia decrease in contamination intensity. The Pearson's correlation between the analyzed microelements in soil and wheat indicates that there was only a correlation between $\mathrm{Cd}$ content in the wheat and the soil (0.494), indicating that this element entered the wheat from soil. The content of $\mathrm{Pb}$, $\mathrm{Hg}, \mathrm{As}, \mathrm{Zn}$ and $\mathrm{Fe}$ in the wheat grain is invariant to their content in the soil samples.

Keywords Toxic microelements - Soil $\cdot$ Wheat . Principal component analysis

\section{Introduction}

Soil is a fundamental natural resource on which life depends. The process of soil formation happens over a very long period of time; on the other hand, degradation of soil is much faster and happens over a very short period of time. The agricultural soils of Banat and Bačka (regions in Serbia's northern province of Vojvodina; geographic coordinates of Vojvodina: latitude $45.3167^{\circ} \mathrm{N}$, longitude $19.8500^{\circ} \mathrm{E}$ ) should receive considerable attention in view of their natural potential. Hence, soil monitoring is required in order to safeguard this vital resource and to ensure the production of healthy food and high and stable yield.

Pollutants enter the soil from many sources. The substances containing heavy metals (HMs) are among most important. As a result, soil pollution may be caused by $\mathrm{Cd}$ that enters soil through phosphorous fertilizers. Other sources of soil pollution are $\mathrm{Pb}$, found in soil close to roads with heavier traffic flow, and $\mathrm{Cu}$, which is reported to be present in higher concentrations in the soil of fruit and vineyard regions, etc. (Ubavić and Bogdanovic 2001). It was determined that plants do not react in an equal way to a copper deficit in the soil (Ubavić and Bogdanovic 2001). 
Wheat is one of the plants with great sensitivity to a deficit of this element, so this element needs special attention in wheat-growing soils where its deficit is reported (Ubavić and Bogdanovic 2001).

Plants must absorb necessary macro-biogenic elements as well as micro-biogenic elements from the soil in order to grow and develop. Sufficient concentrations of biogenic elements in soil are necessary to provide a high and stable crop yield of good quality (Zeremski-Škorić et al. 2011). Plants also have an important role in the distribution of toxic element ions in nature. They enter the food web mainly through plants grown in polluted soils (ZeremskiŠkorić et al. 2011), so knowledge of the mechanisms of accumulation, distribution and metabolism of toxic elements in plants is essential.

$\mathrm{Pb}$ accumulation is more intensive in the roots than the shoots. The high capacity of the root to accumulate lead ions could protect the shoots from a higher lead concentration found in the environment (Weber and Hrynezuk 2000).

Generally, the elements are more intensively accumulated in the root than in the shoots, while the lowest level of accumulation is in the grains. Weber and Hrynezuk (2000) conducted laboratory tests to investigate the assimilation of elements $(\mathrm{Cd}, \mathrm{Pb}$ and $\mathrm{Zn})$ in wheat by exposing leaves to those elements and by adding solutions of these metals to soils. The assimilation of lead from the soil was insignificant, which led to the conclusion that $\mathrm{Pb}$ enters plants from the air through the leaves. Furthermore, it was reported that lower concentrations of $\mathrm{Zn}, \mathrm{Cd}$ and $\mathrm{Pb}$ also accumulated in some parts of the wheat (grain, stem), either through uptake from the contaminated soil through the root system or from the air through the leaves (Weber and Hrynezuk 2000).

Today, wheat is one of the three most important cereal crops in the world because it is used for bread and pastry production as well as other flour products.

Wholegrain wheat is a rich source of vitamins and minerals. It also contains vitamin B complex, vitamin E, K, $\mathrm{Ca}, \mathrm{Mg}, \mathrm{P}$ and cellulose fibers.

Wheat contains larger amounts of proteins than other cereal crops; consequently, wheat and wheat products are recommended in everyday nutrition (Škrbic and Onjia 2007). In addition, wheat grain contains essential microelements $(\mathrm{Cu}, \mathrm{Zn}, \mathrm{Fe}, \mathrm{Mn}$ and $\mathrm{Ni})$, which directly or indirectly affect human health. However, these biogenic elements are toxic if present in excessive concentrations (Carbonell-Barrachina et al. 2002).

Wheat is often grown in soils along road sides with heavy traffic flow where exhaust gases from motor vehicles are released into the atmosphere and may have harmful effects on the soil and plants (Hjortenkrans et al. 2006). Davies and Holmes (1995) found that a $\mathrm{Pb}$ content of $0.45 \mathrm{~g} / \mathrm{l}$ in petrol and the 24 -h traffic volume resulted in an increase in the concentration of lead in the air on both sides of the road of $1 \mu \mathrm{g} / \mathrm{m}^{3}$ per 1,000 vehicles.

Traffic-related soil pollution occurs near roads with a traffic density above 20,000 vehicles per day (Hjortenkrans et al. 2006). The emission of fine lead particles from automobile exhaust, which may also be adsorbed directly through the leaves, results in lead uptake in roadside vegetation. Petrol car engines also emit other microelement particles found in various oil additives used for engines or transmission systems (Nwachukwu et al. 2010).

Mineral fertilizers and pesticides used in wheat production may be contaminated with insecticides based on toxic elements: $\mathrm{Pb}, \mathrm{Cd}$, As or $\mathrm{Hg}$. Due to the slow $\mathrm{Pb}, \mathrm{Cd}$, As and $\mathrm{Hg}$ excretion from organisms, carcinogenic and mutagenic effects caused by chronic toxicity may occur (Ybanez and Montoro 1996; Abrahams 2002; Agunbiade and Fawale 2009), along with acute intoxication caused by toxic doses taken over extended periods (6 months to 2 years).

According to the current Regulation on the quantities of pesticide, metals, metalloids and other toxic substances, drugs, anabolic and other substances that could be present in foodstuffs (Serbian Regulations 1992), the maximum permissible concentration levels of $\mathrm{Pb}, \mathrm{Cd}, \mathrm{Hg}$ and $\mathrm{As}$ in wheat are $0.4,0.1,0.05$ and $1 \mathrm{mg} / \mathrm{kg}$ of dry matter.

The objective of this research was to investigate the presence of toxic microelements $(\mathrm{Pb}, \mathrm{Cd}, \mathrm{Hg}, \mathrm{As}, \mathrm{Zn}, \mathrm{Cu}$, $\mathrm{Fe}$ and $\mathrm{Mn}$ ) in selected agricultural soils and in wheat grown in Banat and Bačka and to analyze correlations between toxic elements in the soil and in the wheat. The results of the investigation will provide information on the possibility of growing wheat in soils close to roads and on reducing the harmful effects of pollutants released from fuel burning on the soil and wheat.

The results will be of great importance for bread and pastry manufacturers when deciding whether to use the wheat in bread and whole meal wheat products.

The study was conducted in Banat and Bačka, Serbia in June-October 2011.

\section{Materials and methods}

\section{Material}

The study area consisted of ten sites in Banat and Bačka, alongside roads with heavy traffic flow, as illustrated in Fig. 1.

Three composite soil samples were taken at three points, each at a different distance from the road (at 3, 100 and $200 \mathrm{~m}$ from the road). Ten soil samples were taken from each point and mixed together to make a composite sample representative of that part of a particular site. Samples were 
Fig. 1 Origins of the samples

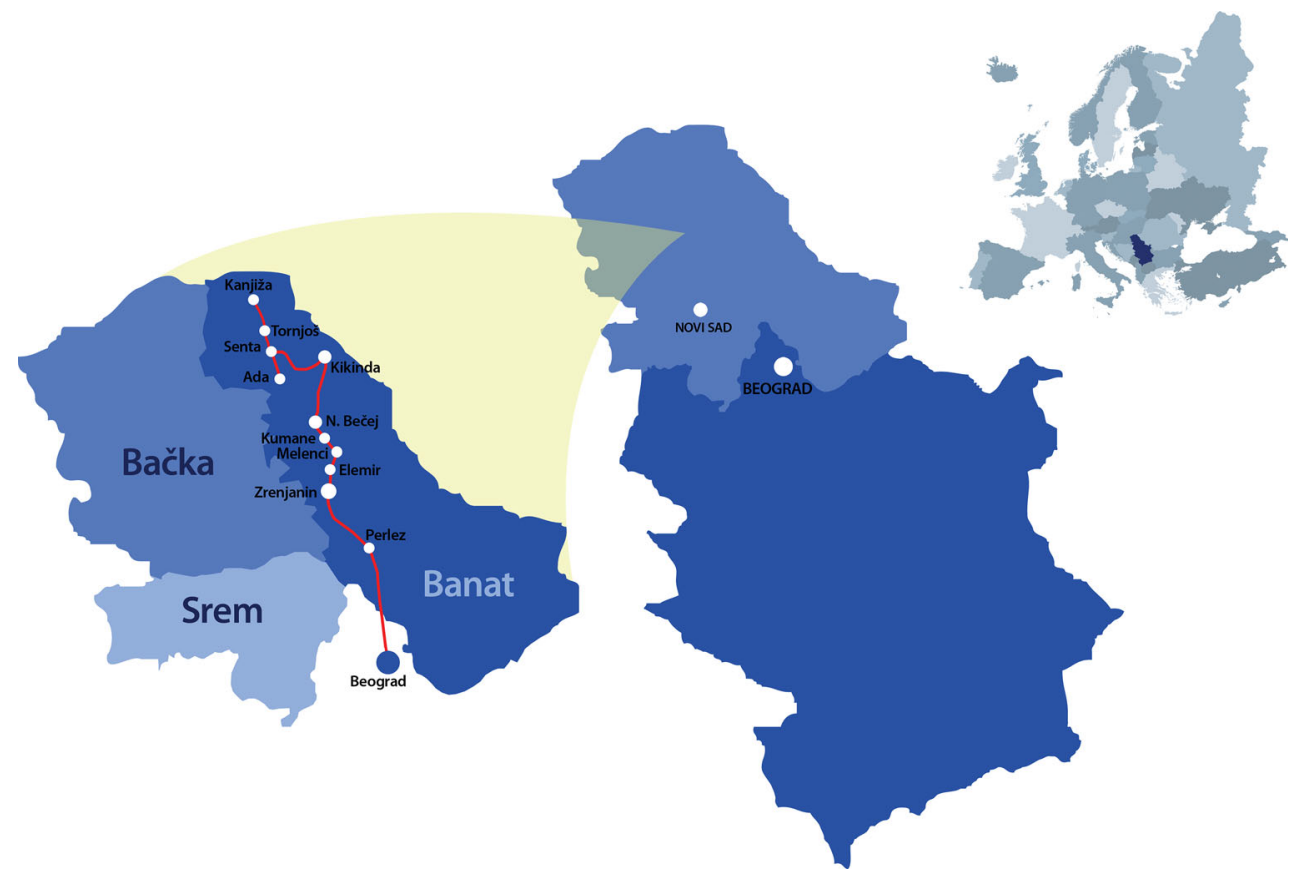

taken in the same way from each site, so a total of 30 composite soil samples were collected and analyzed.

The samples of analyzed wheat were collected from the same sites as the soil samples. During harvest, three composite wheat samples were taken at three points, each at a different distance from the road (at 3,100 and $200 \mathrm{~m}$ from the road), which were obtained by mixing ten individual samples of wheat. A total of 30 soil samples and 30 wheat samples were analyzed.

Soil sampling techniques and analytical methods

Metal contents in the soils were analyzed after a microwave assisted digestion of the samples (Luo et al. 2007) using a multiwave 3000 microwave oven. The procedure was based on 3051A (US EPA, 1998). The aliquot of $0.5 \mathrm{~g}$ of each sample was measured and then digested with a mix of $9 \mathrm{ml}$ of $\mathrm{HNO}_{3}$ and $3 \mathrm{ml}$ of $\mathrm{HCl}$. As recommended by the US EPA Method 3051A, the temperature of the samples was raised to $170{ }^{\circ} \mathrm{C}$ in less than $5.5 \mathrm{~min}$ and remained between 170 and $180{ }^{\circ} \mathrm{C}$ for the balance of the $10 \mathrm{~min}$ irradiation period. After digestion, the solutions were filtered through Whatman No. 1 filter papers, and the volumes were adjusted to $50 \mathrm{ml}$ using double deionized water $(18.2 \Omega)$.

The concentrations of $\mathrm{Pb}, \mathrm{Cd}, \mathrm{As}, \mathrm{Hg}, \mathrm{Zn}, \mathrm{Cu}, \mathrm{Fe}$ and $\mathrm{Mn}$ were measured using inductively coupled plasma mass spectrometry (Elan 9000, ICP-MS).

Each recording was repeated eight times. Samples blanks analysis were done to correct for external contributions, while standards from the National Institute of
Standard and Technology (USA) were obtained and subjected to the same analytical process to evaluate the recovery, accuracy and to ensure quality control of the method. Recoveries ranged from $97 \%$ for $\mathrm{Hg}$ to $105 \%$ for Cd.

Preparation and analysis of the wheat samples

The wheat samples were ground in a water-cooled mill (1095KNIFTEC Sample Mill) and homogenized. A $0.5 \mathrm{~g}$ sample was dissolved in $10 \mathrm{ml}$ of concentrated $\mathrm{HNO}_{3}$ and heated under reflux. After dissolution, $10 \mathrm{ml}$ of concentrated perchloric acid was added and heated until the formation of nitrous fumes stopped. The digestion temperature did not exceed $85{ }^{\circ} \mathrm{C}$ to prevent loss of As and $\mathrm{Hg}$ (the temperature range was from 70 to $85^{\circ} \mathrm{C}$ ). The solution was placed in a $50 \mathrm{ml}$ volumetric flask and made up to volume with deionized water (18.2 $\Omega$ ).

Samples were analyzed depending on the type of elements and their concentration by inductively coupled plasma mass spectrometry (Nexion 300 ICP-MS, Perkin Elmer).

Appropriate quality assurance procedures and precautions were carried out to ensure the reliability of the results. Samples were generally carefully handled to avoid contamination. Glassware was properly cleaned and the reagents were of analytical grade. Reagent blank determinations were used to calibrate the instrument readings. A recovery study of the analytical procedure was carried out by spiking and homogenizing several previously analyzed samples with varied amounts of standard solutions of the 
metals. Recoveries ranged from $97 \%$ for $\mathrm{Hg}$ and $\mathrm{Fe}$ to $102 \%$ for $\mathrm{Cu}$ and $\mathrm{Cd}$. It is evident that the concentrations of toxic elements determined agreed well with the reported certified values, confirming the accuracy of the procedure applied.

\section{Heavy metals index (HMI)}

Central tendency is most widely used to compare the HMI content of complex samples determined using multiple assays (Sun and Ho 2001), where samples are ranked based on the mean value and standard deviation of the assays used. Since the units and scale of the data from various assays are different, the data in each data set should be transformed into standard scores, according to the following equation:

Standard score $=(x-\mu) / \sigma$

where $x$ represents the raw data, $\mu$ the mean and $\sigma$ the standard deviation (SD). When averaged, the standard scores of a sample for different assays give a single unitless value termed the HMI, which is a specific combination of data from different chemical assays with no unit limitation and no variance among the methods.

\section{Statistical analysis}

Descriptive statistical analyses for calculating the means and the standard error of the mean were performed using the StatSoft Statistica 10 software. All the results obtained were expressed as the mean \pm standard deviation (SD). The evaluation of the correlation matrix, one-way analysis of variance (ANOVA), Levene and Brown-Forsythe's tests of homogeneity of variances, and an $F$ test of the results obtained were performed using the StatSoft Statistica 10 software. Comparison of means and significant differences between specific soil and wheat samples are determined according to post hoc Tukey's HSD test with a $p<0.05$ significant level and $95 \%$ confidence limit, using StatSoft Statistica 10 .

In order to enable a more comprehensive comparison between investigated samples HMI, assigning equal weight to all HM assays applied was introduced. Correlation analysis, ANOVA and $F$ test, as well as Levene and Brown-Forsythe's tests, were applied to show the relations between the applied HMs. Post hoc Tukey's HSD tests with a $95 \%$ confidence limit were calculated to show any significant differences between different soil and wheat samples. Low coefficients of variation were calculated that confirmed the finding on the high accuracy of the HM assays. Principal component analysis (PCA) was applied to classify and discriminate the analyzed samples. A pattern recognition technique was applied within the assay descriptors to characterize and differentiate soil and wheat samples.

\section{Results and discussion}

Toxic microelement content in the wheat

The concentrations of analyzed microelements in the collected wheat samples is shown in Fig. 2. The greatest differences are detected in the concentrations of $\mathrm{Pb}$, ranging from 0.11 to $0.23 \mathrm{mg} / \mathrm{kg}$, Mn from 30.64 to $69.82 \mathrm{mg} /$ $\mathrm{kg}$, Fe from 27.17 to $51.52 \mathrm{mg} / \mathrm{kg}$ and $\mathrm{Zn}$ from 12.20 to $48.53 \mathrm{mg} / \mathrm{kg}$.

All microelements exhibited a progressive decrease in contamination intensity that is strongly associated with increased distances from the roads (Fig. 2). The results obtained indicate that, it is necessary to change the current legislation (Regulations on fuel quality enacted in 1990) and to introduce regulations requiring the use of lead-free fuels, which would result in a significant decrease in lead concentration in the areas along the roads.

The mean values of $\mathrm{Pb}$ were $0.143 \mathrm{mg} / \mathrm{kg}$. The results show that $\mathrm{Pb}$ concentration in the analyzed wheat was lower than the concentrations found in the tests reported by Nan et al. (2002) where the total content of $\mathrm{Pb}$ found in the flour samples was $0.520-1.030 \mathrm{mg} / \mathrm{kg}$, and also lower than the concentrations found in the tests performed by Hussan et al. (2011) where $\mathrm{Pb}$ concentration was $0.30 \mathrm{mg} / \mathrm{kg}$.

The measured concentrations of the analyzed elements led to the conclusion that they were below the maximum levels prescribed in the Regulations (1992).

The maximum allowed concentrations prescribed by the European Commission (1997) are $0.2 \mathrm{mg} / \mathrm{kg}$ of $\mathrm{Cd}$ in wheat grain and $0.1-0.2 \mathrm{mg} / \mathrm{kg}$ of $\mathrm{Pb}$ in cereals, while the presence of any $\mathrm{Hg}$ and As in foodstuffs is unacceptable.

As a result of traffic or vehicle activities and the use of petrol with lead additives, the reported concentrations of lead measured in the wheat samples collected from locations close to the roads (Fig. 2) are higher than the concentrations prescribed by the FAO/Commision (1998a, 1998b).

Descriptive statistical analysis was calculated separately for each assay to provide some basic information, within the applied assays (Fig. 2). The coefficient of variation (CV) was calculated for HM assays. The lowest $\mathrm{CV}$ was found for the determination of Mn content (0.09\%), while the $\mathrm{CV}$ for measuring $\mathrm{Fe}$ and $\mathrm{Zn}$ content was found to be 0.29 and $0.74 \%$, respectively. The accuracy of $\mathrm{Pb}, \mathrm{Cd}, \mathrm{Cu}$ and As content determination was also very good, with CVs obtained of 1.28, 1.23, 1.50 and $2.99 \%$, respectively. The $\mathrm{CV}$ for $\mathrm{Hg}$ content determination was found to be $10.48 \%$. Levey-Jennings charts showed no violation of 
Fig. 2 The total concentration of toxic elements $(\mathrm{mg} / \mathrm{kg})$ in wheat grain taken from the sites at different distances from the road
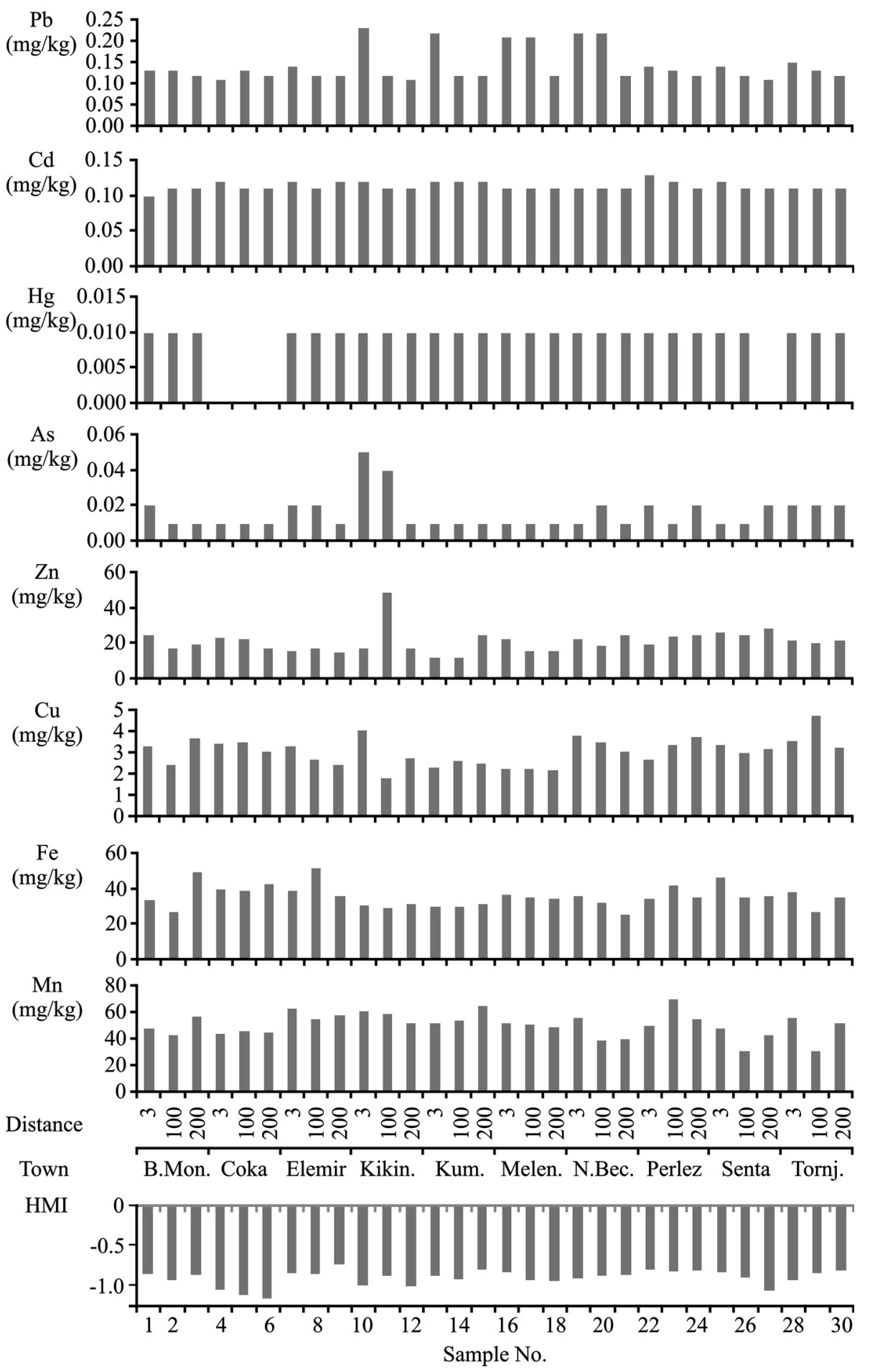

the six basic rules of the Westgard scheme during the measurements (rules $1_{2 \mathrm{~s}}, 1_{3 \mathrm{~s}}, 2_{2 \mathrm{~s}}, \mathrm{R}_{2 \mathrm{~s}}, 3_{1 \mathrm{~s}}$ and $4_{1 \mathrm{~s}}$ were used, where the number represent the number of control observations, and the subscript represents the statistical limit for evaluating the control observations). Only $3.3 \%$ of the valid quality check (QC) values fall between $2 \cdot \mathrm{SD}$ and 3.SD limits and therefore, the quality of the analytical results can be considered adequate.

According to Ludajić and Filipović (2009), the Cd ion content in the samples of wheat grown in Central Banat over the period $2003-2007$ was lower $(0.065 \mathrm{mg} / \mathrm{kg})$ than the obtained concentration levels (Fig. 2). 
Table 1 The maximum allowed concentrations of certain elements in soil

\begin{tabular}{lc}
\hline Elements & MAC in soil $\mathrm{mg} / \mathrm{kg}$ of soil \\
\hline Cadmium & 3 \\
Lead & 100 \\
Mercury & 2 \\
Arsenic & 25 \\
Copper & 100 \\
Zinc & 300 \\
\hline
\end{tabular}

The one-way ANOVA test was calculated for the HMs content in wheat grain, accompanied by the $F$ test. According to the $F$ test comparison between effects, Mn content $(F=3,000.6)$ was found to be the more influential variable for the final result than $\mathrm{Zn}(F=2,773.4)$ or $\mathrm{Fe}$ $(F=1,609.0)$, significant at $p<0.01$ level, $95 \%$ confidence limit. According to the Levene test of the homogeneity of variances, the Fe assay was found more influential compared to the $\mathrm{Mn}$ and $\mathrm{Zn}$ assays. Like $\mathrm{CV}$, BrownForsythe's test also shows that Fe content is more influential then $\mathrm{Mn}$ and $\mathrm{Zn}$ assays. These findings confirm that $\mathrm{Mn}, \mathrm{Fe}$ and $\mathrm{Zn}$ assays are more accurate compared to other applied assays.

The concentrations of biogenic elements in wheat grain were between the usual higher and lower levels and complied with the maximum allowed concentrations of $\mathrm{Cu}$ $(10 \mathrm{mg} / \mathrm{kg})$, and $\mathrm{Zn}(40 \mathrm{mg} / \mathrm{kg})$ in wheat in Bulgaria as reported by Bojinova et al. (1996). However, they have not yet been not regulated in the Regulations of the Republic of Serbia (1992).

The reported concentration of zinc in the wheat grown in the vicinity of the metal foundry in Kikinda (situated at $45.84^{\circ} \mathrm{N}, 20.45^{\circ} \mathrm{E}$ ) was $48.53 \mathrm{mg} / \mathrm{kg}$. The increased content of zinc in comparison to other analyzed samples is the result of its presence in the soil (Fig. 2) surrounding the metal foundry, which is the main source of zinc contamination.

The post hoc Tukey's HSD tests were evaluated for comparison between the HMs content in wheat grain samples within each of the experimental methods used, and a statistically significant difference was found in almost all samples, at a significance level, $p<0.05$ and $95 \%$ confidence limit (Fig. 2).

Toxic element content in soil

The maximum allowed microelement concentrations in the soil according to the Regulation on the maximum levels of dangerous and harmful substances found in soil and irrigation water and methods for their testing (Serbian Regulations 1994) are shown in Table 1.
The content of lead in the soil samples in all tested localities, regardless of the distance from the road (Fig. 3) is far below the maximum allowed concentration. The highest content of lead was found in the locality of Kikinda $(22.205 \mathrm{mg} / \mathrm{kg})$, which accounts for the fact that the soil sample was taken from a site that was alongside roads with heavy traffic flow on the one hand, and the fact that the site was near an industrial zone on the other hand. The most frequent anthropogenic lead contamination of the soil was reported near roads with heavy traffic flow and resulted from vehicle exhaust emissions. The average lead content found in all the analyzed soil samples was $17.389 \mathrm{mg} / \mathrm{kg}$, which implies that the analyzed soils were not lead contaminated since the permitted quantity of lead was $100 \mathrm{mg} /$ $\mathrm{kg}$ (Table 1).

ANOVA was also calculated together with the $F$ test for HMs content in soil. According to the $F$ test comparison between effects, Mn content $(F=78,640.0)$ was found to be the more influential variable for the final result, then $\mathrm{Zn}$ $(F=2,885.4) \quad$ or $\mathrm{Fe} \quad(F=2,699.02)$, significant at $p<0.01$ level, $95 \%$ confidence limit.

The post hoc Tukey's HSD tests were evaluated for comparison between the HMs content in the soil samples within each of the experimental methods used, and statistically significant difference was found in almost all samples, at a significance level of $p<0.05,95 \%$ confidence limit (Fig. 3).

According to Brankov et al. (2006), $\mathrm{Zn}$ in soil originates from the parent substrate. Mineral fertilizers rarely contain more than $100 \mathrm{mg} / \mathrm{kg}$ of copper and their long application in field experiments did not cause copper contamination of the soil. The content of copper in the analyzed soil samples varied from 13.936 to $31.601 \mathrm{mg} / \mathrm{kg}$ (Fig. 3) and that quantity is consistent with the data reported by Ubavić and Bogdanovic (2001).

Ubavić and Bogdanovic (2001) reported that in fruit and vineyard regions in Vojvodina, the quantity of copper is between 1 and $50 \mathrm{mg} / \mathrm{kg}$, which corresponds with the measured content of copper in the locality of Čoka and Perlez (Fig. 3) because the samples were taken from agricultural soil near orchards.

Table 2 shows the Pearson correlation coefficients between HM assays in wheat grain samples, while Table 3 indicates the correlation between HM assays in soil samples and Table 4 displayed the correlations between HM assays in the soil and wheat grain samples.

The adoption of HMs on the sites closer to main roads is more evident in the soil samples (by comparison between Figs. 2, 3), thus indicating that wheat does not accumulate many of the analyzed elements in its grains.

A statistically significant positive correlation of 0.494 (at level $p<0.01$ ) was observed between $\mathrm{Cd}$ content in wheat grain and its content in soil, which indicates that 
Fig. 3 The total concentration of toxic elements $(\mathrm{mg} / \mathrm{kg})$ in the soil at different distances from the road
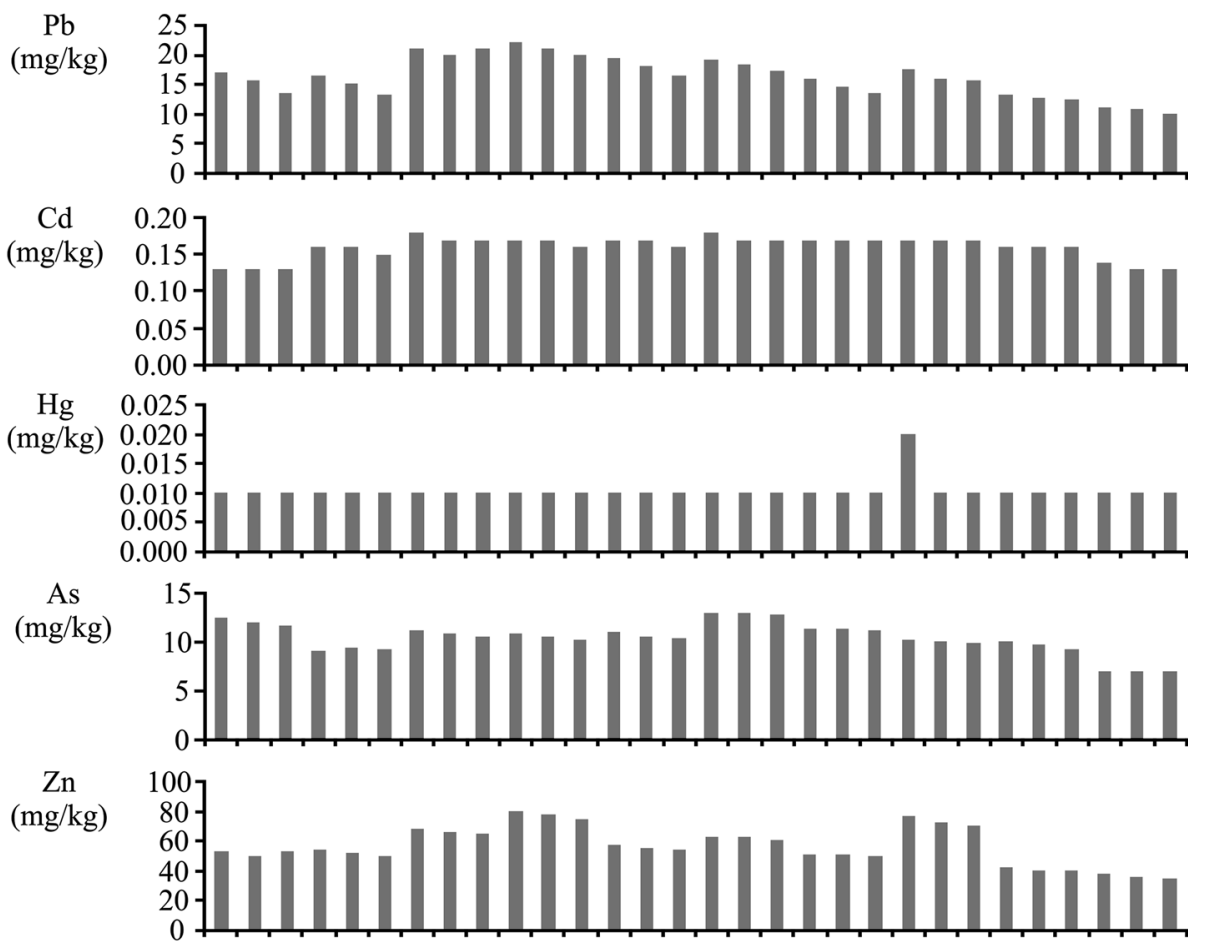

$\mathrm{Cu}$

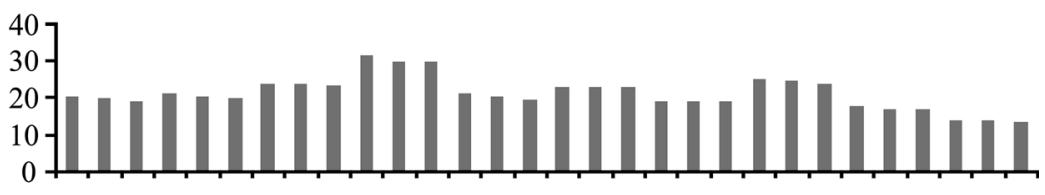

$\mathrm{Fe} \quad 40000$
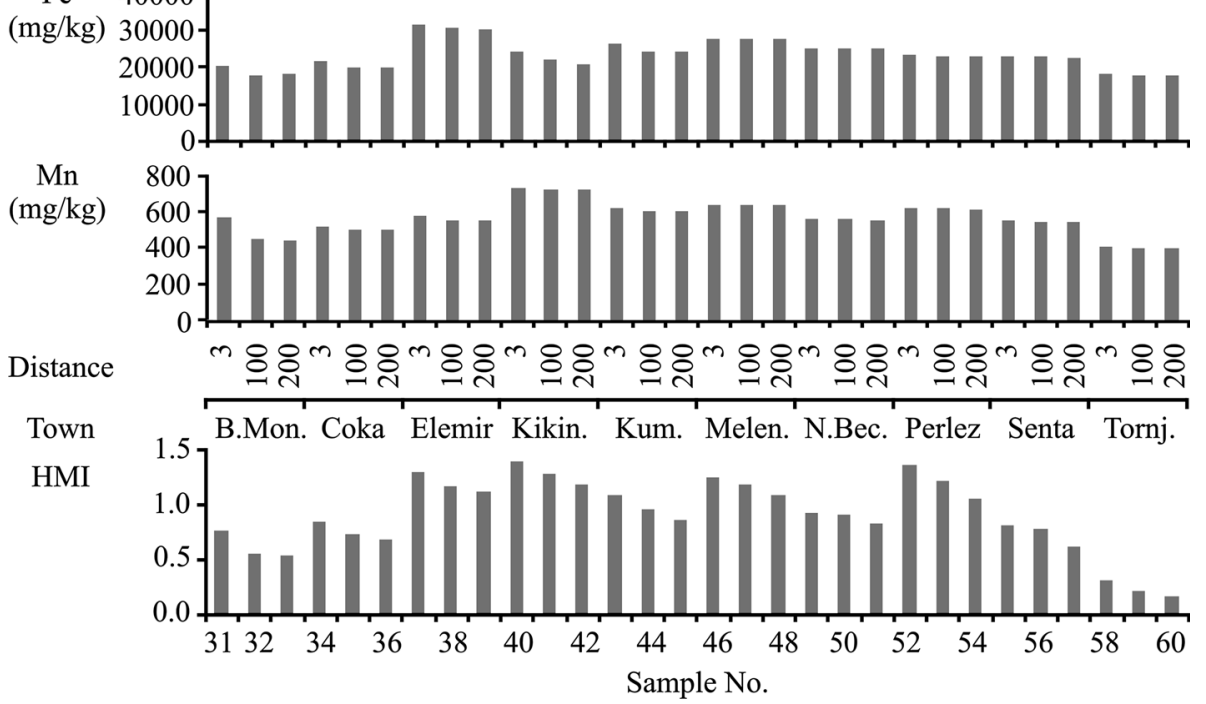

wheat adopts $\mathrm{Cd}$ from the soil. Cd enters agricultural land via applied phosphorus fertilizers, according to statistically nonsignificant differences between many samples (Figs. 2 and 3). Cd content in wheat grain is statistically significant with most of the other HM assays in soil samples (except for As), indicating that pollution of these HMs was induced by phosphorous fertilizers as well. A positive correlation coefficient with 0.403 (statistically significant at $p<0.05$ level) was also observed between the Mn content in wheat grain and soil samples, and the content of $\mathrm{Mn}$ in wheat grain can be associated with its content in soil samples. A statistically significant negative correlation (at level $p<0.10$ ) was observed between $\mathrm{Cu}$ content in wheat grain and soil samples. 
Table 2 The Pearson correlation coefficients between HM assays in wheat grain samples (3,100 and $200 \mathrm{~m}$ from the road), with statistical significance expressed as $p$-level values, written in small parentheses

\begin{tabular}{|c|c|c|c|c|c|c|c|}
\hline & $\mathrm{Cd}$ & $\mathrm{Hg}$ & As & $\mathrm{Zn}$ & $\mathrm{Cu}$ & $\mathrm{Fe}$ & Mn \\
\hline \multirow[t]{2}{*}{$\mathrm{Pb}$} & 0.057 & $0.109^{* *}$ & $0.171^{*}$ & $-0.238^{+}$ & 0.058 & $-0.149^{*}$ & 0.066 \\
\hline & $(0.38)$ & (0.09) & $(0.01)$ & $(<0.01)$ & $(0.37)$ & $(0.02)$ & $(0.31)$ \\
\hline \multirow[t]{2}{*}{$\mathrm{Cd}$} & & 0.067 & 0.064 & $-0.132^{*}$ & -0.082 & 0.004 & $0.180^{+}$ \\
\hline & & $(0.31)$ & $(0.33)$ & $(0.04)$ & $(0.21)$ & $(0.96)$ & $(<0.01)$ \\
\hline \multirow[t]{2}{*}{$\mathrm{Hg}$} & & & $-0.254^{+}$ & $-0.281^{+}$ & $-0.119^{* *}$ & -0.064 & $0.173^{+}$ \\
\hline & & & $(<0.01)$ & $(<0.01)$ & $(0.07)$ & $(0.32)$ & $(<0.01)$ \\
\hline \multirow[t]{2}{*}{ As } & & & & $0.400^{+}$ & $0.152^{*}$ & $-0.227^{+}$ & $0.174^{+}$ \\
\hline & & & & $(<0.01)$ & $(0.02)$ & $(<0.01)$ & $(<0.01)$ \\
\hline \multirow[t]{2}{*}{$\mathrm{Zn}$} & & & & & -0.053 & -0.057 & 0.021 \\
\hline & & & & & $(0.42)$ & $(0.38)$ & $(0.75)$ \\
\hline \multirow[t]{2}{*}{$\mathrm{Cu}$} & & & & & & $0.141^{*}$ & $-0.204^{+}$ \\
\hline & & & & & & $(0.03)$ & $(<0.01)$ \\
\hline \multirow[t]{2}{*}{$\mathrm{Fe}$} & & & & & & & $0.243^{+}$ \\
\hline & & & & & & & $(<0.01)$ \\
\hline
\end{tabular}

+ Significant at $p<0.01$ level; * significant at $p<0.05$ level; $* *$ significant at $p<0.10$ level

Table 3 The Pearson correlation coefficients between HM assays in soil samples (3, 100 and $200 \mathrm{~m}$ from the road), with statistical significance expressed as $p$-level values, written in small parentheses

\begin{tabular}{|c|c|c|c|c|c|c|c|}
\hline & $\mathrm{Cd}$ & $\mathrm{Hg}$ & As & $\mathrm{Zn}$ & $\mathrm{Cu}$ & $\mathrm{Fe}$ & Mn \\
\hline \multirow[t]{2}{*}{$\mathrm{Pb}$} & $0.586^{+}$ & 0.033 & $0.569^{+}$ & $0.846^{+}$ & $0.853^{+}$ & $0.661^{+}$ & $0.762^{+}$ \\
\hline & $(<0.01)$ & $(0.62)$ & $(<0.01)$ & $(<0.01)$ & $(<0.01)$ & $(<0.01)$ & $(<0.01)$ \\
\hline \multirow[t]{2}{*}{$\mathrm{Cd}$} & & $0.209^{+}$ & $0.360^{+}$ & $0.565^{+}$ & $0.526^{+}$ & $0.786^{+}$ & $0.690^{+}$ \\
\hline & & $(<0.01)$ & $(<0.01)$ & $(<0.01)$ & $(<0.01)$ & $(<0.01)$ & $(<0.01)$ \\
\hline \multirow[t]{2}{*}{$\mathrm{Hg}$} & & & 0.003 & $0.158^{*}$ & 0.089 & 0.084 & $0.140^{*}$ \\
\hline & & & $(0.97)$ & $(0.02)$ & $(0.17)$ & $(0.20)$ & $(0.03)$ \\
\hline \multirow[t]{2}{*}{ As } & & & & $0.453^{+}$ & $0.454^{+}$ & $0.529^{+}$ & $0.515^{+}$ \\
\hline & & & & $(<0.01)$ & $(<0.01)$ & $(<0.01)$ & $(<0.01)$ \\
\hline \multirow[t]{2}{*}{$\mathrm{Zn}$} & & & & & $0.952^{+}$ & $0.456^{+}$ & $0.810^{+}$ \\
\hline & & & & & $(<0.01)$ & $(<0.01)$ & $(<0.01)$ \\
\hline \multirow[t]{2}{*}{$\mathrm{Cu}$} & & & & & & $0.391^{+}$ & $0.844^{+}$ \\
\hline & & & & & & $(<0.01)$ & $(<0.01)$ \\
\hline \multirow[t]{2}{*}{$\mathrm{Fe}$} & & & & & & & $0.493^{+}$ \\
\hline & & & & & & & $(<0.01)$ \\
\hline
\end{tabular}

+ Significant at $p<0.01$ level; * significant at $p<0.05$ level; ** significant at $p<0.10$ level

The content of $\mathrm{Pb}, \mathrm{Hg}, \mathrm{As}, \mathrm{Zn}$ and $\mathrm{Fe}$ in wheat grain is invariant to their content in the soil samples.

A statistically significant, negative correlation of $-0.254 ;-0.281 ;-0.227$ and -0.204 (at level $p<0.01$ ) was observed between: $\mathrm{Hg}$ and $\mathrm{As} ; \mathrm{Hg}$ and $\mathrm{Zn}$; $\mathrm{As}$ and $\mathrm{Fe}$; and $\mathrm{Cu}$ and $\mathrm{Mn}$ content, respectively (Table 2). No significant correlation $(-0.003)$ was found between $\mathrm{Hg}$ and As for soil samples, indicating that $\mathrm{Hg}$ pollution is not from the soil (also observed in the PCA graphic, and Table 4).
The PCA allowed the detection of a structure in the relationship between the assays used and different HM assays that give complimentary information. The full normalized data matrix consisting of two measured samples (soil and wheat grain), ten different sites, three different locations (3, 100 and $200 \mathrm{~m}$ distance from the road), and eight measured parameters $(\mathrm{Pb}, \mathrm{Cd}, \mathrm{Hg}, \mathrm{As}, \mathrm{Zn}, \mathrm{Cu}, \mathrm{Fe}$ and $\mathrm{Mn})$ were submitted to the PCA. All the samples in different categories gained different scores as predicted by the 
Table 4 The Pearson correlation coefficients between HM assays in soil and wheat grain samples (3, 100 and $200 \mathrm{~m}$ from the road), with statistical significance expressed as $p$-level values, written in small parentheses

\begin{tabular}{|c|c|c|c|c|c|c|c|c|}
\hline \multirow[b]{2}{*}{ Soil samples } & \multicolumn{8}{|c|}{ Wheat kernel } \\
\hline & $\mathrm{Pb}$ & $\mathrm{Cd}$ & $\mathrm{Hg}$ & As & $\mathrm{Zn}$ & $\mathrm{Cu}$ & $\mathrm{Fe}$ & $\mathrm{Mn}$ \\
\hline \multirow[t]{2}{*}{$\mathrm{Pb}$} & 0.260 & $0.402^{*}$ & 0.105 & 0.300 & -0.132 & $-0.491^{+}$ & -0.095 & 0.533 \\
\hline & $(0.17)$ & $(0.03)$ & $(0.58)$ & $(0.11)$ & $(0.49)$ & $(<0.01)$ & $(0.62)$ & $(<0.01)^{+}$ \\
\hline \multirow[t]{2}{*}{$\mathrm{Cd}$} & $0.360^{* *}$ & $\mathrm{0.494}^{+}$ & -0.021 & 0.037 & -0.035 & $-0.333^{* *}$ & -0.020 & 0.282 \\
\hline & $(0.05)$ & $(<0.01)$ & $(0.91)$ & $(0.85)$ & $(0.85)$ & $(0.07)$ & $(0.92)$ & $(0.13)$ \\
\hline \multirow[t]{2}{*}{$\mathrm{Hg}$} & 0.076 & $0.553^{+}$ & 0.024 & -0.003 & 0.057 & 0.026 & 0.280 & 0.038 \\
\hline & $(0.69)$ & $(<0.01)$ & $(0.90)$ & $(0.99)$ & $(0.76)$ & $(0.89)$ & $(0.13)$ & $(0.84)$ \\
\hline \multirow[t]{2}{*}{ As } & $0.386^{*}$ & -0.052 & 0.239 & -0.145 & -0.172 & $-0.485^{+}$ & -0.041 & 0.192 \\
\hline & $(0.04)$ & $(0.79)$ & $(0.20)$ & $(0.44)$ & $(0.36)$ & $(<0.01)$ & $(0.83)$ & $(0.31)$ \\
\hline \multirow[t]{2}{*}{$\mathrm{Zn}$} & 0.137 & $0.448^{*}$ & 0.025 & $0.372^{*}$ & 0.024 & $-0.349^{* *}$ & -0.026 & 0.595 \\
\hline & $(0.47)$ & $(0.01)$ & $(0.90)$ & $(0.04)$ & $(0.90)$ & $(0.06)$ & $(0.89)$ & $(<0.01)^{+}$ \\
\hline \multirow[t]{2}{*}{$\mathrm{Cu}$} & 0.134 & $0.353^{* *}$ & -0.141 & $0.447^{*}$ & 0.067 & $-0.355^{* *}$ & -0.068 & 0.495 \\
\hline & $(0.48)$ & $(0.06)$ & $(0.46)$ & $(0.01)$ & $(0.73)$ & $(\mathbf{0 . 0 5})$ & $(0.72)$ & $(<0.01)^{+}$ \\
\hline \multirow[t]{2}{*}{$\mathrm{Fe}$} & 0.294 & $0.360^{* *}$ & $0.355^{* *}$ & -0.110 & -0.274 & $-0.416^{*}$ & 0.097 & $0.315^{* *}$ \\
\hline & $(0.12)$ & $(0.05)$ & $(0.05)$ & $(0.56)$ & $(0.14)$ & $(0.02)$ & $(0.61)$ & (0.09) \\
\hline \multirow[t]{2}{*}{$\mathrm{Mn}$} & 0.262 & $0.326^{* *}$ & -0.082 & $0.321^{* *}$ & 0.143 & $-0.444^{*}$ & -0.239 & $0.403^{*}$ \\
\hline & $(0.16)$ & $(0.08)$ & $(0.67)$ & $(0.08)$ & $(0.45)$ & $(0.01)$ & $(0.20)$ & $(0.03)$ \\
\hline
\end{tabular}

Bold values indicate statistical significance

+ Significant at $p<0.01$ level; * Significant at $p<0.05$ level; ** Significant at $p<0.10$ level

PC score plot. The variability of the results in the data set is large, so different categories are formed according to the assays obtained.

For visualizing the data and the discriminating efficiency, a scatter plot of samples using the first two PCs issued from PCA of the data matrix (also called scores plot) was obtained (Fig. 4). As can be seen, there is a neat separation between the soil (31-60) and the wheat grain (1-30) samples, according to $\mathrm{Pb}, \mathrm{Cd}, \mathrm{Hg}, \mathrm{As}, \mathrm{Zn}, \mathrm{Cu}, \mathrm{Fe}$ and Mn content. The first two PCs, accounting for $96.26 \%$ of the total variability, were considered sufficient for such data. $\mathrm{Pb}, \mathrm{Cd}, \mathrm{As}, \mathrm{Zn}, \mathrm{Cu}, \mathrm{Fe}$ and $\mathrm{Mn}$ content were found more influential for the first factor calculation (each factor contributed 12-13\%), while $\mathrm{Hg}$ content contributed $87.6 \%$ for the second factor.

\section{Conclusion}

Considering the results of the analysis of toxic element content in wheat and soil, it could be concluded that:

Statistically significant differences for toxic element content were observed between almost all wheat grain samples, at $p<0.05$ level, $95 \%$ confidence limit, thus emphasizing the adverse influence of the vicinity of heavy traffic.

The ANOVA test and $F$ test for Mn content in wheat grain $(F=3,000.6)$ showed greater variance compared to

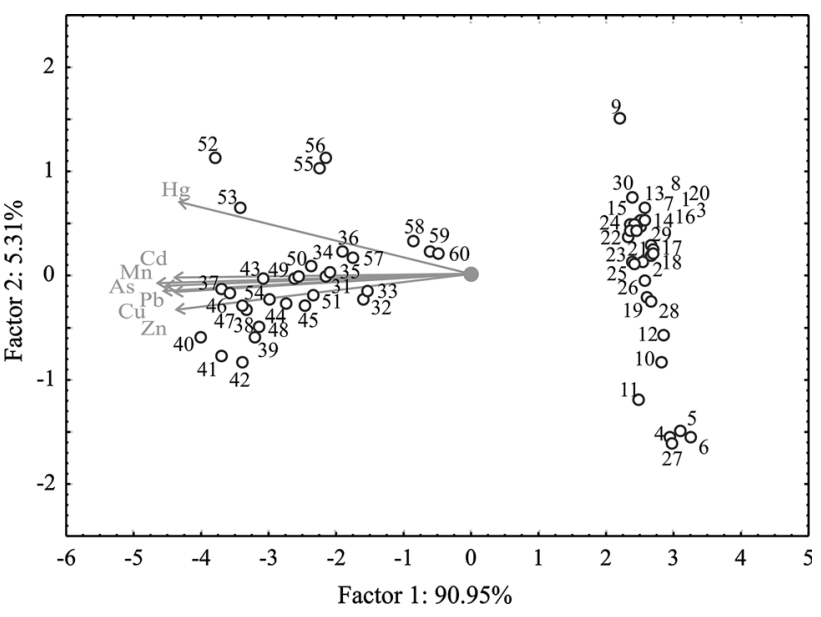

Fig. 4 Biplot for toxic element content in wheat grain (samples $1-30)$ and soil (31-60)

other elements, indicating that samples taken in different locations differ significantly due to $\mathrm{Mn}$ influence. For Fe and $\mathrm{Zn}, F$ is 1,609.0 and 2,773.4, respectively. According to the ANOVA and $F$ test at $p<0.01$ level, $95 \%$ confidence limit used for toxic element content analysis in soil, it was established that Mn content $(F=78,640.0)$ was a more influential variable for the final result, followed by $\mathrm{Zn}$ $(F=2,885.4)$ or $\mathrm{Fe}(F=2,699.02)$.

The level of $\mathrm{Pb}$ concentration in wheat samples taken from the sites alongside the roads is higher than the level prescribed in the EU regulations. 
The content of $\mathrm{Pb}, \mathrm{Hg}, \mathrm{As}, \mathrm{Zn}$ and $\mathrm{Fe}$ in wheat grains complies with their content in the soil.

No significant correlation $(-0.003)$ was found between $\mathrm{Hg}$ and $\mathrm{As}$ for soil samples, indicating that $\mathrm{Hg}$ pollution is not from the soil.

Based on the correlation between microelements in the wheat grain and the content of analyzed elements in the soil, there was a correlation between $\mathrm{Cd}$ content in wheat and soil (0.494), which indicates that this element entered the wheat from the soil.

The position of points attributed to samples within the factor plane indicated the content of HMs, showing that there is far less HMs in the wheat grain than in the soil.

With the aim of preventing the presence of toxic elements in whole meal wheat products, it is necessary to perform regular quality control of wheat in different agroecological conditions.

Acknowledgments The results are part of a project supported by the Ministry of Education and Science of the Republic of Serbia, TRI 46005 .

\section{References}

Abrahams PW (2002) Soils: their implications to human health. Sci Total Environ 291:1-32

Agunbiade FO, Fawale AT (2009) Use of Siam weed biomarker in assessing heavy metal contaminations in traffic and solid waste polluted areas. Int J Environ Sci Technol 6(2):267-276

Bojinova P, Georgiev B, Kabakchiev I, Krasteva V, Stanislavova L, Tchuldjian H, Welp G (1996) In: Terytze K (ed) Harmonization of the methods for the investigation of heavy metal pollution of soils and the standardization of the assessment criteria for soil protection. Report No. UBA-FB 96-071

Brankov M, Ubavić M, Sekulić P, Vasin J (2006) Trace element and heavy metal contents of agricultural and nonagricultural soils in the region of Banat, vol 42. Institute of Field and Vegetable Crops, Novi Sad, pp 167-177

Carbonell-Barrachina AA, Garcia E, Sanchez Soriano J, Aracil P, Burlo F (2002) Effects of raw materials, ingredients, and production lines on arsenic and copper concentrations in confectionery products. J Agric Food Chem 50:3738-3742

Davies BE, Holmes PL (1995) Heavy metals in soils. Blackie Academic \& Professional, Glasgow, pp 206-223
European Commission (1997) Draft Commission Regulation setting maximum limits for certain contaminants in foodstuffs, Doc III/ $5121 / 95$ Rev 3

FAO/WHO (1998a) Discussion paper on cadmium. Agenda item 15 (d). CX/FAC 99/21, 1998

FAO/WHO (1998b) Discussion paper for lead. Agenda item 15 (b). CX/FAC 99/19, 1998

Hjortenkrans D, Bergback B, Haggerud A (2006) New metal emission patterns in road traffic environments. Environ Monit Assess 117:85-98

Hussan I, Ali Khan I, Ali J (2011) Comparative studies of heavy metals in wheat growing in different environmental conditions. J Chem Soc Pak 33(4):499-502

Ludajić G, Filipović N (2009) Review of the content of lead and cadmium ions in wheat grain. Ecologica 16:397-400

Nan Z, Zhao C, Li J, Chen F, Sun W (2002) Relations between soil properties and elected heavy metal concentrations in spring wheat (Triticum aestivum L.) grown in contaminated soils. Water Air Soil Pollut 133:205-213

Nwachukwu MA, Feng H, Alinnor J (2010) Assessment of heavy metal pollution in soil and their implications within and around mechanic villages. Int J Environ Sci Technol 7(2):347-358

Regulation on the quantities of pesticide, metals, metalloids and other toxic substances, drugs, anabolic and other substances that could be present in foodstuffs ("Official Gazette of the Federal Republic of Yugoslavia" No. 5/92, 11/92- amend. and $32 / 2002$ and ("Official Gazette of the Republic of Serbia" No. $25 / 2010$ - regulation and 28/2011)

Regulation on the maximum levels of dangerous and harmful substances found in soil and irrigation water and methods of their testing ("Official Gazette of the Republic of Serbia" No. 23/94)

Regulation on the technical and other requirements for liquid fuels (Official Gazzette of the Republic of Serbia, No, 36/90)

Škrbić B, Onjia A (2007) Multivariate analyses of microelement contents in wheat cultivated in Serbia. Food Control 18:338-345

STATISTICA (Data Analysis Software System) (2010). v. 10., StatSoft, Inc., USA. www.statsoft.com

Sun T, Ho CT (2001) Antiradical efficiency of tea components. J. Food Lip. 8:231-238

Ubavić M, Bogdanović D (2001) Agrohemija. Faculty of Agriculture, Novi Sad, pp 133-138

Weber R, Hrynezuk B (2000) Effect of leaf and soil contaminations on heavy metals content in spring wheat crops. Nukleonika 45:137-140

Ybanez N, Montoro R (1996) Trace element food toxicology: an old and ever-growing discipline. Crit Rev Food Sci Nutr 36:299-320

Zeremski-Škorić T, Ninkov J, Sekulić P, Milić S, Vasin J, Lazić N (2011). Quality of soils in Kindergarten playgrounds in The City Of Novi Sad. XV international eco-conference, Novi Sad, Serbia, 21-24th September 